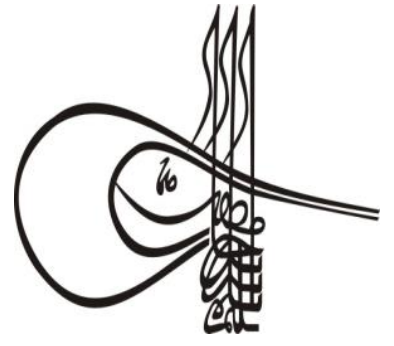

\section{Language and Literature}

Volume 14 Issue 4,2019, p. 1767-1788

DOI: 10.29228/TurkishStudies.24971

ISSN: 2667-5641

Skopje/MACEDONIA-Ankara/TURKEY

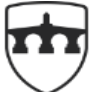

INTERNATIONAL BALKAN UNIVERSITY

EXCELLENCE FOR THE FUTUR IBU.EDU.MK

Research Article / Araştırma Makalesi

$\underline{\text { Article Info/Makale B ilgisi }}$

Received/Geliș: 19.07.2019

VAccepted/Kabul: 20.12.2019

\title{
KUTADGUBİLİG PERSPEKTİFINDE ERBÂB-I MESLEK VE ASHÂB-I AHLÂK
}

bayat atı birle sözüg başladım törütgen igidgen keçürgen idim (Bismillahirrahmanirrahim)

\author{
Timuçin AYKANAT*
}

\begin{abstract}
ÖZ
Yûsuf Has Hacib tarafindan 1069-1072 y1llar1 arasında tamamlanan Kutadgubilig özgün adlı "mutluluk veren bilgi", siyasetnâme edebî türünün etkin ve manzum bir örneği olarak; mesnevî formunda yazılmıs ve geçis dönemi Türk edebiyatının nadideleri arasında yer edinmiş önemli bir yapittır. Dört temel kahraman ve sonsuz anlam katmanı etrafinda; mensur ve manzum birer mukaddime ve 6645 aslî beyit ile kendi içinde tutarlı tafsilâttan mürettep Kutadgubilig, yaşamsal bir öğreti kitabı olarak didaktik kurguda ve toplumsal bazdadır. Bu yönüyle; söz konusu eserin, Kuranıkerim'den mülhem olduğu varsay1labilir.

Kuranıkerim, tüm insanlığa ortak eksende seslenen ve her anlamda yol göstermeyi deneyen ilâhî kimlikli bir eserdir. Aynı perspektifte; Kutadgubilig de her çevre ve çerçeveden insanın alg1 odağına seslenen ve onları yönlendirebilecek dînî-alegorik kimlikli bir eserdir. Devri öncesi tüm âsâr-1 ehemmiyeyi inhisar eden Kutadgubilig, bir sosyo-edebî mahsül olarak; toplumları oluşturan bireylerin hemen çoğu adına anlamlar taşır. Olması gereken; bu anlamsal değerleri, toplumlarla ve bireyleri ile buluşturmaktır.

Birçok değerli biliminsanı Kutadgubilig kapsamında oldukça kaydadeğer ve özverili çalışmalar yapmıştır. Bu bağlamda; söz konusu çalışma, haciplik mertebesine erişmiş bir yüce kişilik gözünde; yaşamları güzel kılan ahlâkın ve ancak erbabınca icra edildiğinde nimet
\end{abstract}


ve rahmet veren mesâlikin örneksel ve ezgisel düzlemdeki yansımalarını ortaya koyuyor. $\mathrm{Bu}$ doğrultuda; Kutadgubilig'in sosyo-algısal ve düşünsel yönü, dramatize edilmiş oluyor.

Anahtar Kelimeler: Yûsuf Has Hacib, Kutadgubilig, Ahlâk, Mesâlik, Sosyo-edebiyat.

\title{
COMPETENT VOCATIONAL AND OWNERS-MORALITY IN KUTADGUBILIG PERSPECTIVE
}

\begin{abstract}
Kutadgubilig's original "blissful knowledge an", which was completed by Yûsuf Has Hacib between 1069-1072, is an effective and verse example of politicame literary genre; It is an important work written in mathnawî form and has become one of the rarities of the transitional Turkish literature. Around four basic heroes and layers of infinite meaning; Kutadgubilig, the prose and verse, one of the holy writers and 6645 original couplets, consistent with their own details, are in a didactic fiction and social basis as a vital teaching book. In this aspect; It can be assumed that the work in question was an excerpt from the Qur'ân.

My Qur'an is a work of divine identity that addresses all humanity on a common axis and tries to guide in every sense. In the same perspective; Kutadgubilig is a work of religious-allegorical identity that addresses and directs the perception of human beings from every environment and frame. Kutadgubilig, which was the exclusive of all the important Works before the reign of the Ottoman Empire, as a socioliterary product; it has meanings on behalf of the majority of individuals who make up societies. Must be; these semantic values, societies and individuals to bring together.

Many esteemed scientists have done considerable and devoted work within the scope of Kutadgubilig. In this context; the work in question, in the eyes of a supreme personality that has reached the level of foreclosure; it reveals the exemplary and melodic reflections of morality that makes lives beautiful and the occupation that gives blessing and mercy only when performed by virtue. In this direction; The socio-perceptual and intellectual aspect of Kutadgubilig is dramatized.
\end{abstract}

\section{STRUCTURED ABSTRACT}

Kutadgubilig; holiness felicity information, the state of knowledge, the state administration information from the meaning of the work started by Yûsuf Has Hacib in Balasagun began to be written. In 10691070 was completed in the city of Kasgar in Eastern Turkistan and East Karahan; ruler Tavgaç Ulug Bugra Kara Han Ebu Ali Hasan bin Arslan was presented.

The human-centered work shows the ways in which people who live both as individuals and in communities are governed by good politics and be held in the world and the hereafter to be happy. It does 
this by making use of the dialogue between the four main people who are given symbolic names. Allegorically, the four individuals that are created in this work represent four different ideas and tasks. Of these, Küntogdi represents the law, justice and justice, Aytoldi is the vizier, happiness represents the mind and science of Aytoldr's son and the other son of Aytoldi's Odgurmus.

Kutadgubilig, written during the periods when Turks entered Islam, placed great importance on the tradition of Islam and the understanding of the old Turkish state on the one hand, in order to reach people on the basis of individual and society.

The honor ((honor) created by the arrangement of the customary law practices of Turkish tribes by the great Turkish rulers and the fortune, mentioned by the Turkish ruler by God are the basis of Turkic states and Turkish sovereignty. It constitutes.

It is no doubt that it was possible for the Turkics to establish great states in every period of history and to direct the world politics of these states in their periods due to a good state organization. Turks who give great importance to their old lives and traditions. After accepting the Islamic religion, they could not quickly break from their customs. Because of this, Yusuf wrote a very good analysis of the conditions of the period he lived in writing his work.

The work was written to show people the way to be truly blessed in the world. Yusuf Hâs Hacib used the measure of prosody in his work. The section constituting the main part of the work, which is collected under approximately 88 titles with the additions, is written with the abbreviated consecutor, ie the fa'ulun fa'ulun fa'ulun fa'ul and the meter (see only one complete quatrain in the quaternary: see 38003801). 1-6520. couplets rhyme among themselves in mesnevi style. A part of 44 couplets (couplet 6521-6564), which speaks of pity and youthfulness of the pieces added to the end of the work, is in full prosperity (fâilün fâilün fâilün fâilün) and continues in ode style and aa ba ca. A piece of 40 couplets (couplet 6565-6604), which speaks of the disorder of time and the cefas of friends, is in the meter and style of the previous piece. The 41 couplets (6605-6645 couplets), which mentions the owner of the book, Ulu Hâs Hacib Yusuf, to give him advice on his own, are in the shortened consecutive meter and kaside style.

It is seen that the measure of prosperity, which was presumed to be new in Turkish literature for that period and was conceived, was used smoothly by the poet except for the rhyme in the additional parts. The work is written in half story and half representation style, and includes monologues that prepare the movement and scenes with live depictions.

It is contemporary with Kaşgârlı Mahmut and his work Divânü Lügati't-Türk, and the fact that it was written in almost the same years is also remarkable in terms of the reputation that Turkish saw in that period.

The work is full of philosophical truths that extend to the present and the future and will never lose its validity. The work discusses the problems of education, morality, politics and society, especially philosophy, together with its previous accumulation of ideas and carries

\section{Turkish Studies - Language and Literature}

Volume 14 Issue 4, 2019 
values such as knowledge, reason, truth, justice, happiness and understanding to today's people.

Yusuf Has Hacib, who could also be called a philosopher, based his work on four basic people and the values that he represented: the ruler Kün-Toğd1 represents justice, the vizier Ay-Told1 happiness, the son of vizier Ögdülmiss mind and the relative of the queen Odgurmıs represents conviction.

According to Yusuf Has Hacib, happiness is the same. There is no happiness that goes on in the same way. Happiness grows like the moon and shrinks over time. In fact, the work wants to emphasize that the differences between happiness and happiness should be seen and it is perfect.

Keywords: Yûsuf Has Hacib, Kutadgubilig, Morality, Professions, Socio-literature.

\section{Giriş}

Erki yönlendirmek ve erke yön vermek niyetiyle yazılan siyasetnâme tarzı yapıtlar, asılda toplumu ve özelde bireyleri hedef alır. Buna rağmen; esere olacak teveccüh ve rağbet kaygısı, tarzı siyasetnâme olan yapıtların, devlet erkânına veya erkine atfolunmasını tesis eder. Kutadgubilig de bu tarzda eserlerdendir. Yine de; söz konusu eser, muhatabı olan her birey ve bireylerden oluşan toplumu ilgi dairesinde tutmuştur. Bu anlamda; Kutadgubilig, didaktik ve manzum bir öğreti kitabıdır.

Türk-İslâm edebiyatının en eski ve muteber örneklerinden birini sunan Kutadgubilig, Türk kimliğinin doğru alımlanmasında ve Türk kültürel yaşamsallığının sağlıklı bir çerçeveye oturtulmasında sözsel sahiplik taşımaktadır. Bu doğrultuda; sağlıklı ve sağlam kuşakların yetiştirilmesi adına bir başucu kitabı niteliği taşıyan Kutadgubilig, aynı nesil ve topluma teşkilatlanmacı ve birleşimci bir yaşam algısı sunması yönüyle de etkindir. Bu bağlamda Kutadgubilig, yazıldığı devir ve çevrenin toplumsal yapısı ve düşünsel yönü ile ilgili fikirler verirken; Türklerin komşu millet ve kültürlerle olan alışverişini de gözler önüne serer.

Aydın bir kimlik tarafından sabır gerektirecek bir zaman zarfinda kaleme alınan ve Tabgaç Buğra Han'a takdim olunan Kutadgubilig nâm-1 eser, Türk edebiyatında aruz vezni ile yazılmış ve mesnevî formunda tanzim olunmuş ilk örnek olarak kabul görmüştür. Müellif Yûsuf Has Hacib, eserine birer mensur ve manzum mukaddime ile toplamda 6645 beyti içkin uzun bir anlamsal katman yerleştirmiştir. Klasik Türk edebiyatı eser tanzimi teamülüne uygun olarak tertip edilen Kutadgubilig,Fe'v̂lün/Fe'ûlün/Fe'ûlün/Fe'ûl kalıbıyla yani; Şehnâme vezni ile dizgilenmiştir. Her bir fasılası, ayrı bir başlık altında etraflıca değerlendirilmiş ve her madde başı toplumun bir başka algısallığına değinen Kutadgubilig, gerçekten de adıyla aynı eksende muhatabı olan her kimseye “mutluluk veren bilgi” olabilmektedir.

Türk-Uygur geleneğinin bir uzantısı ve İran şiirselliğinin epistomolojik bir yansıması görünümünde olan Kutadgubilig, üç temel nüshası ve hayli seçkin bilimsel kimlikli çalışmayla günümüze taşınmıştır. Söz konusu irdelemelerin en anlamlısı hiç kuşkusuz değerli biliminsanı Prof. Dr. Reşid Rahmeti Arat'a aittir. Arat'a ait; tanıtım, takdim, tetkik, neşir, dil içi çeviri ve sistemli dizin sunan Kutadgu Bilig adlı çalışma, ilmi değerinin yanında kutsallığın bir taşıyıcısı olarak ender ve eşsizdir. (Arat, 2008: 7-1285)

Karahanlı dönemi Türkçesi ile şiirselleştirilmiş Kutadgubilig, didaktik olduğu kadar alegoriktir de. Dört temel kahraman etrafinda biçimlendirilmiş Kutadgubilig'in hükümdar tipi Kün Togdı, adaleti; vezir tipi Ay Toldı, bahtı; vezir mahdumu Ögdilmiş, aklı ve vezirin kardeşi Odgurmış,

\section{Turkish Studies - Language and Literature}

Volume 14 Issue 4, 2019 
akıbeti temsil eder. Bu timsaller, eserin sunduğu didaktizmin yanında alegori ile de makyajlandığı gösterir niteliktedir. Güncel bakış açısı ile birçok sembolik/izlenimci anlatıma yer veren Kutadgubilig, tasavvufî bir öğreti olan temkin basamağını da çokça güzel örnekler. Hatt-1 zatında; söz konusu eser, bireyden topluma ve yöneticilere varıncaya dek; hemen herkesin ehl-i temkin olmasının aklî bulunduğunu aşılamayı dener.

Çinlilerin "Edebü'l-Mülûk", Maçinlilerin "Âyinü'l-Memleke", Maşrıklılarm "Zînetü'l- Ümerâ", İranlıların "Şâhnâme-i Türkî" veya "Pendnâme-i Mülûk", Türklerin ise "Kutadgu Bilig" dedikleri mevzubahis eser, sözcükten, tümceye; tümceden metne, metinden pasaja, pasajdan tümele varasiya; dil, edebiyat, sosyoloji, felsefe, mantık vb. birçok hususta hacimli ya da az hacimli birçok çalışmanın ilgi odağını oluşturmuştur. Bu oluşumsallık içerisinde; görülmüştür ki Kutadgubilig, dîni ve edebî bilgisi hayli yüksek bir bilgin tarafından; kültürel bir ayıklık ve kazanmışlık tesis etmek adına yazıya dökülmüş̧ür. Eserin, dinî-toplumsal yaşam değerlerini özverili ve tutarlı bir biçimde sunması ve bunun yanında biçimsel benzeşlik sağlama kaygısı taşıması yönleri ile Kuranıkerim'den mülhem olduğu öne sürülebilir. Elbette ki; kitabın, dinî ve ilâhî bir kimlikle dinsel kutsallık taşıma ve belki sunma gibi bir iddiası yoktur. Ancak şurası unutulmamlıdır ki; mezkûr eser, belirtilen durumu, mânen ve maddeten başarmıştır.

"Kutadgu Bilig, baş tarafına sonradan ilave edilen manzum ve mensur metinlerden de anlaşılacağı üzere, bir idare ve siyaset kitabıdır. Yusuf Has Hacib bu eserde, çeşitli konu ve meseleler hakkında felsefi ve sosyolojik fikir ve düşünceler ileri sürüp öğütler vermektedir. Bundan başka, toplumu oluşturan çeşitli sınıf ve zümrelerin yapısını ve değerini, onlara karşı hükümdar tarafindan izlenmesi gereken davranış ve tutumları belirlemektedir. Böyle olmakla birlikte, Kutadgubiilig'in, eski devirlerde Doğu'da benzerlerine sıkça rastlanan türden, devrin idarecilerine ve devlet adamlarına pratik tavsiyelerde bulunmak ve adaletli bir yönetim oluşturmalarını istemek amacıyla ahlaki telkinler veren, devlet içindeki sosyal gruplaşmaları göz önüne seren, tarihin tanınmış şahsiyetlerinin yaptıklarından örnekler sunan öğüt kitapları durumundaki siyasetnâme (nasîhâtü'lmülûk)'lerden farklı ve özgün bir yapısı vardır." (Adalığlu, 2009: 237-253)

Kutadgubilig, sunduğu zengin dilsel ve edebî verilerin yanında; çokça toplumsallık da paylaşır. Bunların başında; devlet yönetimi, hükümdar ve adalet kavramları gelir. (Büyükbaş ve Vargün, 2016: 27-33) Muhteşem lakabıyla anılan Kanunî Sultan Süleyman'ın aynı zamanda şair de bulunmak dolayısıyla; gerek şiirsel açıdan ve gerekse yönetimsel bağlamda Kutadgubilig'den müstefit olduğu muhakkaktır. (Kesik, 2002: 237-240)

Dîvân-ı Lugati't-Türk (Akkoyunlu ve Ercilasun, 2015: 1-995) ile paydaş ve bağlamdaş birçok dilsel ve edebî değeri içkin Kutadgubilig, sunduğu mefhumlar açısından da hayli zengindir. (Aydemir, 2013: 803-810) Özellikle bilgiye çokça kıymet ve yer veren Yûsuf Has Hacib, eğitimin önem ve değerine de dikkati çeker. (Kaya, 2017: 1-26)

Eğitime anılan cihetten değer veren ve onu işleyen Kutadgubilig, eğitim psikolojisi ve eğitim felsefesi ile alakalı işlevselliklere de yer verir. Ulasal ve insani kimlikte birçok algı ve ifade değerini içkin Kutadgubilig, her şeyin üstünde değer ve değerler eğitimi açısından tam anlamıyla hedefini vurmuş bir Türklük okudur. (Akar, 2016: 546-555)

Kutadgubilig, zamanından sonra kaleme alınan birçok edebî esere nüve sağlamıştır ve ilham olmuştur. Birçok edip ve kültür insanı, söz konusu eserden hareketle çarpıcı yapıt kesitleri ve yapıtlar oluşturmuştur.Makalat, bunların başında gelir. Metinlerarası izleklerin oldukça işlevsel olduğu söz konusu iki çalışma, bu anlamda aynı gayeye hizmet eden iki farklı algısallığın ürünü olmayı başarmıştır.

Kutadgubilig, tasavvufta yer alan renk ilmiyle (Yıldırım, 2006: 129-140) izah edilebilecek biçimde; iki ayrı sıfat tamlaması ve muhteşem bir dizesel oluşum sağlar. Bu oluşum, İslâma hizmet etmiş nice din bilgininin seyr-i sülûkla naklettiği şiirsel bir sürdürücülüktür. (Kara başs yagısı kızıl til

\section{Turkish Studies - Language and Literature}

Volume 14 Issue 4, 2019 
turur/Niçe baş yidi bu takı ma yiyür//Kırmızı dil, kara başın düşmanıdır. O kadar baş yedi, hâlen de yiyor.)

Türkler, yaşamlarının başlangıcından itibaren kadına her dem değer ve önem vermişlerdir. "Hatunum" dediği kadınını anbean yücelten Türk erkeği, özellikle Kitâb-ı Dedem Korkut'la birlikte kadını tahlil ve tevil etmiştir. Yaşamsallığın nadide bir parçası ve sürdürücüsü konumunda olan kadın, Kutadgubilig adlı eser-i edebîyede, işlenen birçok madde başı arasında kendine haysiyetli bir yer bulmuştur. Kadını, yaşamsal statü ve değersellik istikametinde; çok çeşit adlandırma ile işleyen Kutadgubilig, ona en çok da değerli anlamına gelen "kız" tabiri ile işaret eder. (Debreli, 2016: 38-60) Böylelikle; eser, Türklükte kadının ne denli ve ne değerde var olduğunu ayrı bir sentezle göstergeler.

Kutadgubilig'in işleyişselliğine ilişkin madde başlarını tafsilâtlandırmak ve detaylandırmak elbette ki mümkündür. Ancak onun aslî kaygısını paylaşmak daha aklîdir. Kutadgubilig, insan ve kâmil insan ile değeri üzerine konuçlanmıştır. Bu bağlamda insanı yaşamsal bir varlık ve değer olarak işleyen Kutadgubilig, insana afakî değil de ahlâkî yaklaşmasıyla muteber ve rehberdir. (Akgün, 1997: $1-12)$

Kutadgubilig, işlenmiş bir cevahir olmasına karşın; ehl-i ilm, onu çok daha farklı kalıplarda yeniden ve yineleyerek yorumlamıştır. Büyük çoğunluğu; çözümleme, yorum, irdeleme, yazıya dökme, açımlama, metinleştirme ve tamamlama nitelikli olan çalışmalar, müstakil ve mükemmil bir tespitsel çalışmaya işaret edilerek takdim olunabilir. 1825-2016 yılları arasında Kutadgubilig üzerine yapılan yerli ve yabancı bütün ilmi çalışmaları kronolojik olarak verileştiren söz konusu çalışma, hem Kutadgubilig'in bilimsel zenginliğini göstermesi ve hem de yeni açılımlara ilham olması yönleriyle kaydadeğerdir. (Uçar, 2015: 6-47) Bu bağlamda; “mutluluk veren bilgi"nin ahlâkî ve meslekî kapsamda; neler dikte ve telkin ettiği muşîrdir.

\section{Sosyo-Algısal ve Düşünsel Açıdan Kutadgubilig'in Erbâb-ı Meslek Madde Başını Beyan ve Tahlil Eder}

Toplumsal algıya göre; yalnızlık, Allah'a mahsustur. Mahlukat ve özelde insan, her ne koşulda olursa olsun, bir arada ve birliktedir. Tabiatıyla yalnız da değildir. Bir arada yaşamak demek, kişioğlunun yaşamsal alışveriş içerisinde bulunması ve yaşamı paylaşması demektir. Bu durum, çeşitli açılardan, yaşamın her sahasına yansıtılabilir. Meslek ve meslek erbabı olmak da bu kabildendir. İlkokul kitaplarından başlayarak; birçok sosyo-kültürel yapıt, insanın ve özelde meslek erbabı insanların, birbirlerine her dem gereksinim duyduğunu kaydeder. Fırınc1, doktora; doktor, kırtasiyeciye; kırtasiyeci, berbere; berber, kasaba; kasap, daha farklı bir meslek erbabına ihtiyaç duyar. $\mathrm{Bu}$ gereksinmesel paydaşlık, her bir meslek gurubunun kendi dalında özgün ve başarılı olmasını da gerekli kılar. İşte; "mutluluk veren bilgi" , beglik mertebesinden başlayarak; ta ki hizmetkârlara varıcaya dek çok çeşitli erbab-ı mesalik hakkında malumat paylaşır. Bu paylaşım, muhataba hakkıyla yansır ve muhatap, ondan nasiplenirse; birey ve toplum yaşantısı, oldukça berrak bir pozifliğe gark olur. Bu da söz konusu çabanın toplumsal yarar sağlama gayesini haklı çıkarır.

\section{a) Beyliğe Yaraşır Bir Bey Nasıl Olmalıdır?}

Halk anlatıları, "ağalık vermekle; beylik vurmakla olur", der. Oldukça üst düzey bir anlatısal kimlikle kaleme alınan Kutadgubilig, düzeyselliği ile alakalı olarak beylik mefhumuna da yer vermiştir. Kitabın hükümdar tipi Kün Togdı, vezir mahdumu Ögdülmiş'e her daim mutlu, huzurlu ve adil kalacak ve payidar olacak bir beyin nasıl olması gerektiğini sorar. - Bey, nasıl olmalı ki; beyliğinde namı yürüsün, şanı kalsın? Vezir mahdumu Ögdülmiş; bu hususta, hükümdara şunları nakleder: 
yanut birdi ögdülmiş aydı ilig idi ters ayıttı manga bu bilig bu beglik işin barça begler bilir törü öngdi kılk yang olardın kelir anasında togsa togar beglikin körü ögrenür iş bilür yiglikin bayat kimke birse bu beglik işi birür ög köngül kör ol işke tuşı kimi beg törütmek tilese bayat birür aşnu kılk yang ukuş yüg kanat bu beglik işi boldı begler işi bu begler işin bildi beglik kişi bu işni ilig minde yigrek bilür atası beg erdi özi beg turur (1930-1936)

bu beglikke aşnu tüp aslı kerek atım alp katıg kurç yana tong yürek ukuşluk kerek herm biliglig kerek akılık kerek hem siliglik kerek (1949, 1951)

k1lınç edgü erdem kerek ming tümen anın tutsa il kend kötürse tuman

sakınuk kerek beg ne kılkı arıg köngül korksa begler işig tüz kılur (1981, 1985)

uvutlug kerek beg kişide talu uvutlug kılınçı irilmez tolu iki neng turur ilke bagı beki biri saklık ol bir törü il köki (2005, 2015)
Ögdülmiş yanıt verdi ve dedi ki:

Hükümdar bana çok zor bir şey sordu ${ }^{1}$

Bu beylik işini hep beyler bilir;

kanun ve düzen, örf ve âdet onlardan gelir.

Bey doğarken beylikle doğar; görerek öğrenir ve işlerin hangisinin iyi olduğunu bilir.

Tanrl kime bu beylik işini verirse,

ona işiyle oranll akıl ve gönül de verir.

Tanrı kimi bey olarak yaratmak isterse, ona önce uygun tavir ve hareket, akıl ve kol kanat verir.

Bu beylik işi beylerin işidir; beylerin işini bey olan bilir.

Bu işi hükümdar benden daha iyi bilir;

babasi beydi, kendisi de beydir.

Beylik için insan önce asil soylu olmalıdır;

Cesur, yiğit, güçlü ve pek yürekli olmalıdır.

Bey bilgili ve akılli olmalıdır;

cömert ve yumuşak huylu olması da gerekir.

Illeri yönetip barış ve sakinliği săglamak için

hükümdarın iyi tabiatl ve binlerce erdemli olması gerekir.

Bey takva sahibi ve temiz olmall;

aslı temiz olan sürekli temizlik ister.

Bey hayâ sahibi ve seçkin olmall;

hayâ sahibi tavır ve davranış açısından eksiksizdir.

Bir memleketin bağl ve kilidi iki şeyden oluşur;

biri ihtiyatlılık, biri de kanun; bunlar esastır.

\footnotetext{
${ }^{1}$ Yazı boyunca Kutadgubilig özgün ve çeviri metnine yapılan gönderimler, Arat, Reşid Rahmeti (2008). Kutadgu Bilig-Yûsuf Has Hacib.II. Basım, İstanbul: Kabalcı Yayınevi. adlı çalışmaya yönelik olacak; gönderi, sadece beyit numarasına işaret edilmek yoluyla paylaşılacaktır.
} 
sözi çın kerek beg ne k1lkı bütün 1nansa angar halk tirilse kutun bularda eng inga bu arkuk kılınç bu arkuk kılınçlıg ne munglug erinç
Bey doğru sözlü olmalı tavrlyla güven aşılamalı ki, halk ona inansin ve huzur içinde yaşasın. En kötüsü beyde inatçılıktır; inatçı kişi, kuşkusuz çok zorluk çeker.

$(2038,2064)$

$\mathrm{Bu}$ dizelere göre; beyliğin ne demek olduğunu en iyi beyler bilir. Bey, kutalmış ve asil olmalıdır. Bu da ilâhî ve ceddîdir. Bey, mutlak olarak; akıllı, iyi huylu ve erdemli olmalıdır. Asla; inatçı ve güvenilmez bulunmamalıdır. Belirtilen vasıfları haiz bir beyin şemali de malumdur. İlm-i kıyafete göre muteber bir bey, kısa olmamalıdır. Zira kısa insan, hırçın ve kavgacı olur. Bey, orta boylu ve mutedil vücutlu bulunmalıdır. Böyle orantılı olursa itidalden ayrılmaz. İtidalden ayrılmayan da bilge demektir. Bakınız, müellif-i merhum, bunu nasıl dizgilemiş:

bodı kısga yunçıg kılınçı buş1

buş1 kayda bolsa tütüşke baş1

bod ortu kerek hem tenginçe yarag

işing ortu tut ay biliglig kişi

(2089-2090)

bor içmez kerek beg fesad kılmasa

bu iki kılıktın kaçar kut basa
Kısa boylu, bodur kişilerin doğası hırçın olur;

hırçın nereye giderse orada kavga başlar.

Boy orta ve her şey bununla orantill olmall;

her işte itidalden ayrllma ey bilge kişi

Bey içki içmemeli ve fesatlık yapmamall;

bu iki hareket yüzünden sonunda ikbal elden gider.

Örnek beyitler ve açıklamalar gösteriyor ki; bey, her dem ayık kalp ve zihne sahip, 1lıman tabiatlı ve seçkin bir kimse olmalıdır. Böyle bir insan da iç huzura sahip ve kudrete malik olmak dolayısıyla; ashabı ve emlâkını mutmain kılacaktır.

\section{b) Beye Yaraşır Bir Vezir Nasıl Olmalıdır?}

Yönetici anlamına gelen bey, açıklandığı üzere erdemli olmalıdır. Bu vasıfsallık, yaşamın her devresi için var bulunmalıdır. Benzer eksenlilik vezir(ler) için de geçerlidir. Yâver anlamı da taşıyan vezir(lik), mutlak erkin yardımcısıdır. Vezirin nasıl olması gerektiğinin izahı, tıpkı bir beyin nasıl olması gerektiği hususunda olduğu gibi; geçmiş malumattan hareketle güncel yaşantıya 1şık tutacaktır. $\mathrm{Bu}$ anlamda Kutadgubilig, vezir madde başı hakkında şunları telkin eder:

ukuşu öküş bolsa bilgi tengiz

kamug iş bütürse kızartsa mengiz

ulug iş bu işke er ödrüm kerek

bütünlük bile k1lkı ködrüm kerek

sakınuk kerek din idisi arıg

imin bolsa il budnı andın arıg

uvutlug kerek hem közi tok bütün

uvutsuz kişi ol kişide otun

yüzi körki körklüg kerek hem yülüg

kılınçı köni tegse halkka ülüg
Aklı çok, bilgisi deniz gibi derin ve geniş olmall; elinden her iş gelmeli ve yüzleri güldürmelidir. Vezirlik önemli iştir; bu iş için seçkinlik gerekir; vezir doğru ve doğası asil olaml.

Vezir imanll, takva sahibi ve temizolmall; memleket ve halk ondan her türlü emin olmall. Vezir hayâ sahibi, gözü tok ve güvenilir olmall; insanların kabası hayasız adamdir.

Vezirin yüzü güzel ve düzgün,

kendisi de haklıyı tutabilmesi için âdil olmalı. 
yülüg bolsa kaşıg bolur ol vezir vezir bolsa kaşı işi ked yorır sakışçı kerek bolsa bilge tetik bilig birle bilse bu türlüg bitig Kerek kögli kodkı ma yumşak tili $\mathrm{Bu}$ ol kör kişike sevitür yolı tükel kimde bolsa bu erdem bilig vezirlik angar birse bolgay ilig
Saçı sakalı düzgün vezir heybetli olur;

vezir heybetli olursa işi yolunda gider.

Vezirin hesap bilmesi, bilge ve zeki olmasl gerekir;

bilgili olmalı ve çeşitli yazıları bilmelidir.

Vezirin gönlü alçak ve dili yumuşak olmall;

böylelikle kişi kendini başkalarına sevdirir.

Bu erdem ve bilgiler kimde tam olarak bulunursa;

hükümdar vezirliği ona verilebilir.

(2185, 2187, 2190, 2199, 2208, 2217, 2218, 2229, 2238)

\section{c) Ülke Ordusuna Yaraşır Bir Kumandan Nasıl olmalıdır?}

Özellikle Türk ulusu, yaşamsal standart açısından ordu-millet anlayışını taşımaktadır. Güncel anlamda bile halk arasında yaygın bir söylem olan "her Türk asker doğar" tabiri, geçmişten günümüze uzanan çizgide Türk toplumsal ve yaşamsal standartı ile algısını sunmaya yetmelidir. Bu anlamda; Kutadgubilig, ordu kumandanının nasıl olması gerektiğini şöylece teklif eder:

bu işke idi kurç katıg er kerek

başında keçürmiş tükel tong yürek

talu er kerek sak bu işke odug angar tegmese bir usalın yodug ak1 alp atım bolsa alçak köngül tuzı etmeki king ne kılkı amul yüreklig kerek artuk öglüg kerek közüglüg kerek hem köngüllüg kerek yagıda kör arslan yüreki kerek karıştukta esri bileki kerek tonguz teg titimlig böri teg küçi adiglayu azgır kutuz teg öçi yana alçı bolsa kızıl tilkü teg titir bugrası teg kör öç sürse keg sagızganda sakrak kerek tutsa öz kaya kuzgunı teg yırak tutsa köz ulug tutsa hamyet kör arslanlayu ügi teg usuz bolsa tünle sayu bu yanglar bile er yagıçı bolur yagıçı bolur hem yaragçı bolur
Bu işe çok çevik, sert, tecrübeli, tam ve pek yürekli biri gerekir. $B u$ iş için seçkin insan gerekir; ihmalkarlıktan; suçlanmaması için tedbirli ve uyanık olmalı. Cömert, cesur, alçakgönüllü, sofrası açık ve soğuk kanlı olmalı. O çok cesur, zeki ve aynı zamanda da mert ve geniş yürekli olmall.

Onun yüreği savaşta arslan yüreği gibi, dövüşürken de bileği kaplan pençesi gibi olmall. O domuz gibi inatçı, kurt gibi kuvvetli, ayl gibi azılı ve yaban sığırı gibi kinci olmalı. Aynı zamanda kizıl tilki gibi hilekâr olmalı; deve aygırl gibi kin ve öç gütmeli.

Kendini saksağandan daha ihtiyatl tutmall; gözünü kaya kuzgunu gibi uzaklara çevirmeli. Arslan gibi hamiyeti yüksek tutmall; baykuş gibi geceleri uykusuz geçirmeli. Insan bu niteliklerle savaşçı olur; savaşçı olur ve işinin ehli olur.

$(2271,2273,2274,2282,2310,2311,2312,2313,2314,2315)$ 


\section{c) Millete Yaraşır Bir Ulu Hacib Nasıl Olmalıdır?}

Hacib, bilgin demektir. Bir toplumu veya devleti, sevk ve idare eden her nekadar; bey, vezir ve kumandan olsa da asılda onlara yön veren hacibdir. Bilge kişiler belli vasıfları haiz olamlıdır. Bireyden topluma uzanan çizgide bilginler, yaşantısallığın muteber olmasında kaçınılmaz olarak rehber ve kalemleriyle elde teberdir. Bilginin vasfi, bir hacib bulunan Hacib Yûsuf dilinde şöyle tezahür etmiştir:

ulug hacib artuk bütün çın kerek

bu çınlık bile ked bütün din kerek

tüp aslı kerek edgü kılkı ongay

tusulsa budunka togursa kün ay

közi tok kerek hem uvutlug silig

tetiglig kerek hem tümen tü bilig

ukuşlug kerek işte artuk odug

oduglug bile işte tutnur bodug
Ulu hacib çok emniyetli, dürüst ve bu doğrulukla

birlikte iyi ve dini bütün olmall.

Halka yararlı olması ve halka güneş ve ay gibi

doğması için soyu sopu temiz ve ahlâklı olmalı.

Gözü tok, hayâ sahibi ve nazik olmall;

zeki ve bin türlü bilgiye sahip olmall.

Hacib görevde çok uyanık ve anlayışlı olmalı;

insan işinde uyanıklık ile boya tutturur.

$(2436,2437,2441,2453)$

Bundan başka ilm-i kıyafet, hacibin şu biçimde olmasını telkin eder:

kupa körklügüg kör kılın özke fal

Kumral güzeline bak ve onu kendine uğur tut,

işing edgü bolgay kamug sözni üz

işin iyi olur; başka sözü bırak.

\section{d) Hizmete Yaraşır Bir Kapıcıbaşı Nașıl Olmalıdır?}

Kapıcıbaşılık, devlet erkânı yâverliği biçiminde bir vazife olarak; Osmanlı Devleti'nde icra edilen bir meslek olmuştur. Ancak Kutadgubilig'in bu sözden anladığı saray kapıcıbaşısı, saray kapıcısı veya bekçisi olma durumudur. Bir hâneyi tamamlayan kapıdır. Onun güvenlik ve huzurunu tesis edense kapının bekçisidir. Günümüzde kilitler ve görüntülü konuşma sistemlerinin gördüğü bu vazifeyi, eski devirlerde kapıcıbaşılar yerine getirirdi. Her ne kadar kapıcılık hâlen sürdürülen bir meslek olsa da geçmişteki hâlinden çokça ötelerde ve bayağı konumdadır. Üst düzey mekânların kapıcıbaşılığ 1 ise güvenlik ve danışma mensuplarınca yürütülmektedir. Her ne olursa olsun; bu madde başı da tıpk1 ötekiler gibi yaşamsallığa katkı sağlayacaktır. Bakınız, hemen her günü bir olan ve hizmette aynı bulunan kapıcıbaşılar hakkında, "mutluluk veren bilgi" neler nakletmiş:

kapug başlar er ked bagırsak kerek teni canı birle tapugsak kerek kapugda yarutsa karangku tünüg kapugda batursa yarumış künüg törü hem toku bilse k1lsa tapug ongay bolsa kılkı kılınçı kamug tuzu etmeki king akı bolsa ked kümüş birse altun er at tirse ked kiçe bolsa yatgak bu yatsa burun
Kapıcıbaşı olan insan çok sadık olmalı bu hizmeti canla başla benimsemiş olmall. O karanlık geceyi hizmet kapısında ăgırlamalı, parlak güneşi de aynı kapıda batırmalı. Hizmet ederken, usul ve erkân bilmeli; doğası, bütün tavır ve hareketleri ılıml olmalı. Tuzu ekmeği bol ve kendisi de cömert olmall; gümüss ve altın verrerek etrafina yığınlar dirmeli.

Gece olduğunda, yatmadan önce 
ayu birse tegme kişike orun

azak yat baz erse ayitgu kerek

odugrak kim erse yagutgu kerek

körü bekletip çıksa karşı kapug

tükel boldı ol künki barça tapug saray nöbetçilerini gerekli yerlere dikmeli.

Yat ve yabancı kimseleri, iyice soruşturmall;

Açık göz olanları hizmete almalı.

Saray kapısını gözü önünde kapatıp çıkınca,

o günün bütün hizmetini tamamlamış olur. (2529-2535)

\section{e) Liyakatli Bir Ulak/Elçi Nasıl Olmalıdır?}

Liyakat, erbab-ı meslekte aranan en elzem niteliklerden biri olmalıdır. İş, her dem ehline ve liyakatliye teslim edilmelidir. Liyakate ihtiyaç duyulan en önemli mesleklerden biri de elçiliktir. Elçilik tabiri, günümüzde geçmiş kullanımlardan farklı bir boyuta ve kapsama taşınmıştır. Geçmişte bir yerden bir yere haber ulaştırana elçi denirdi. Peygamberler de ilâhî haber ulaştıtıcısı olduklarından aslında birer elçidirler. Anılan dünyevî haber ulaştırma işlemleri, günümüzde artık postacı veya kuryeler tarafindan yürütülmektedir. Günümüzde ilâhî elçilik gerektirecek bir haberin gelmesi ise; imkân ve inanç dâhilinde değildir. Günümüzdeki elçilikler, milletlerarası uzlaşının sağlanmasını tesis etmeye yöneliktir. Bakınız ve ilham alınız, bu konuda vezir mahdumu Ögdülmiş, Kün togdı'ya ne malumat aktarmış:

kamug erde ödrüm yalavaç kerek

biliglig ukuşlug talu ked yürek

ukuşlug kerek ked yalavaç örüg

biliglig kerek sözke bilse yörüg

yana bilse söznüng içi hem taş1

itilse anıng ötrü tüzmiş işi

bagırsak tapugçı beg asgın tiler

beg asgın tilegli begin çın sever

közi suk kişi özke erksiz bolur

bu suklar yalavaçka tengsiz bolur

bilirse sakış yime hendese

'aded cezri kılsa misahat basa

yana nerd-ü santranc bilir erse ked

harifleri andın ulır erse ked

çögenke ked erse atar erse ok

yime kuşçı avçı ajunda ozuk

kamug til bilir erse açsa tilig

kamug batnı bilse bitise elig

bu yanglıg kerek barça erdem bilir

bu yanglıg yalavaç tilekke tegir
Elçi insanlar arasında seçkin, akıllı,

bilgili ve çok yürekli biri olmall.

Elçi çok akullı temkinli ve sözünü

ifade edebilmesi için de bilgili olmalt.

Vazifesinde başarll olabilmesi için bir de

elçinin sözün içini dışını bilmesi gerekir.

Elçi gözü, gönlü tok; içten bağll, güvenilir,

doğru ve doğası dürüst biri olmalıdır.

Açgözlü adam kendine hâkim olamaz;

cimriler, elçiliğe lâyık değildir.

Hesaba, bir de hendeseye vâkıf olmall;

cezir ile mesaha ilmini de bilmeli.

Bundan başka, çok iyi tavla ve santranç

bilmeli, rakiplerini iyice sıkıştırmalı.

Cirit oyununda usta olmall ve oku iyi atmall;

kuşçuluk ve avcrlıkta da başkalarına üst gelmeli.

Konuşurken bütün dilleri konuşmall;

yazarken de bütün yazıları yazmall.

Bütün bu erdemleri bilen insan elçi olur,

böyle bir elçi de işinde muzaffer olur. 
$(2597,2600,2601,2608,2611,2633,2634,2635,2636,2637)$

\section{f) Vazifeye Lâyık Bir Kâtip Nasıl Olmalıdır?}

Arapça kökenli bir sözcük olan kâtip; yazan, yazıcı anlamlarına gelir. Kâtip, bir roman ya da şiir yazıcısından ya da yazanından farklıdır. Roman ve benzeri şeyleri yazana müellif denir. Şiir ve benzeri şeyleri yazana da şair. Kâtip, daha çok resmî yazışmaları kaydeden veya devlet evrâkını tutan kişiye denir. Günümüzde kâtip tabiri, daha çok mahkeme kaydı tutan personele verilen ad biçimindedir. Mecliste de hâlen yazışmaları takip ederek kaydeden görevliler mevcuttur. Kâtiplik, Osmanlı devrinde ilmi mertebe gerektiren bir olguydu. Kâtiplik, günümüzde geçmişte olduğu kadar bilgi ve deneyim gerektiren bir uğraşı olmaktan çıkmıştır. Geçmişte; kâtibin dürüst bir âlim olması şartken; günümüzde hazır veriyi hızlı ve doğru kaydetmesi yeterli olmaktadır. İşte; Kutadgubilig'e göre; kitâbet ve kâtipliğin vasfi:

bitigçike aygu kerek iç sözin

küdezse bitigçi öküş ya azın

bu iç söz tutuglı bütün çın kerek

bütünlükle artuk bütün din kerek

bitigçi biliglig ukuşlug kerek

hat1 uz belagat tak1 edgürek

közi tok kerek hem özi umdusuz

bagırsak kerek çın özi koltgusuz

bor içmez kerek bolsa kılkı arıg

yaraksız kılınçıg yaratsa arıg

bitigçi bu yanglıg kerek ay ilig

1nansa angar birse bolgay elig
Kâtibe sırları söylemek gerekecektir;

kâtip de az ya da çok olsun bunları gizli tutmalı.

Bu sırlara vâkıf olan kişi güvenilir ve dürüst biri ve güven kazanmak için de dini bütün olmalt.

Kâtip bilgili ve akıllı olmalı, güzel bir hatta üstün bir belagata sahip olmall.

Kâtibin gözü tok olmall, tamahkâr olmamall;

doğru, içten bağll ve gönlü zengin olmall.

Kâtip, içki içmemeli ve doğası temiz olmall; yakışıksız hareketleri kendisinden uzaklaştırmalı.

Ey hükümdar! Kâtip böyle olmalıdır;

böyle inanilır ve güvenilir olmalıdır...

$(2675,2676,2693,2721,2729,2737)$

\section{g) Ehil Bir Hazinedar Nasıl Olmalıdır?}

Devletler, beyleri yönetiminde; kanun, mâl, ordu ve inanç güçleriyle ayakta durur. Esasen; kanun, ordu ve inancı daimi kılan da mâldır. İslâm toplumlarında devlet hazinesi, beytülmâl olarak adlandırılırdı. Türk toplumunda "inçü" adı verilen devlet malı, "agıcı" tarafindan korunurdu. Hazinenin genel işlerinden de hazinedarlık yapan agıcı sorumluydu. Günümüzde; millet meclisi ve bakanlıklar bulunduğundan; geçmişteki hazinedarların görevini, ekonomi ve maliye bakanı yürütmekte ve sürdürmektedir. Bu doğrultuda; Kutadgubilig, geçmişten geleceğe uzanan çizgide, hazinedarlık ve yürütücüsü bulunan hazinedarın ne ahvâl taşıması gerektiğini şöylece tarif eyler:

idi çın bütün ked kerek er köni

köngül yaymasa ötrü tutsa munı

öküş neng körü todmış erse közi

yana korkar erse bayatka özi

halal hemö haram adrar erse aça
Beyin gönlüne kuşku girmemesi ve hizmetinde daim olmast için; hazinedar, doğru, dürüst, iyi ve güvenilir olmalı.

Çok mâl görerek gözü doymuş olmalı ve kalbinde Tanrı korkusu bulunmalı. Helal ve haramı iyice ayırt etmeli; 
yaraglıg yaragsıznı bilse seçe

bagırsak kerek hem odug sak tetig

tetiglik bile er k1lur ming itig

uvutlug kerek hem yime ög köngül

uvutsuz kişide yırak tur töngül

bor içmez kerek hem özin tutguçı

özin tutguçı er kutug tapugçı

$\mathrm{Bu}$ işke agıçı saran edgürek

Saranlık bile neng küdezgü kerek

bitigçi kerek uz kamug hat bilir

sakışıg bitigin küdezse kalır

köngül til köni tutsa kılkı bütün

angar tegmese ot yalını tütün

satıgçı kerek bilse türlüg satıg

satig bilmese er kilumaz asıg

kamug neng tavarıg biligli kerek

agırın uçuzun ukuglı kerek

alımka birimke ongay bolsa öz

ulugka kiçigke süçig tutsa söz

bu yanglıg kişi bulsa emdi ilig

ukuşlug biliglig uvutlug silig

angar bilse bolgay agı kaznakı

1nansa yaragay küdezse hak1 yarayanı ve yaramayanı iyice seçebilmeli.

Hazinedar gönülden bağll, uyanık, tedbirli ve zeki

olmalı; insan zekâyla her işte başarllı olur.

O akıllı ve tedbirli olduğu gibi hayâ sahibi de

olmalı; hayâsız kişiden uzak dur, ondan vazgeç.

O içki içmemeli ve nefsine hâkim olmall;

nefsine hâkim olan insan mutluluğu bulur.

Bu iş için eli sıkı bir hazinedar daha iyidir;

hazinenin mâll, tutumla gözetilmelidir.

Muhasebede usta ve her türlü kayıtta mâhir olmalı hesaplarl dikkatlice kaydeden biri bulunmalı. Ateşin alevi ve dumanının ona dokunmaması için gönlü ve dili doğru, hareket ve doğası yaraşmall.

O tüccar olmall ve her türlü ticaretten anlamall;

insan ticaretten anlamazsa kâr edemez.

Bütün eşya ve mâlları bilmeli,

her şeyin pahalısını ucuzunu tanımalı.

Alışverişte tavırları ılımlı olmalı;

büyüğe küçüğe karşı tatlı dil kullanmalı.

Işte hükümdar böyle akıll, bilgili,

hayâ sahibi ve yumuşak huylu birini bulursa,

Hazinesini ve servetini ona burakabilir;

ona güvenir ve hakkını gözetirse yerinde olur.

$(2744,2751,2752,2761,2762,2764,2766,2773,2792,2801,2802,2804,2821,2822)$

\section{Olmalıdır?}

ğ) Nimete Şükredip Hükümdarı Firkreden Hizmette Yaraşır Bir Aşçıbaşı Nasıll

Nimet, belkide yaratılmış en değerli olgudur. Kıymeti bilindikçe rahmet veren nimet, üreticisinden tüketicisine hiçbir kimseye zahmet ve yük olmamalıdır. Nimetin kadri bilinirse; rahmetin ve merhametin de kadri bilinir. Mükellef bir nimet sunumu, aşçıbaşı vesilesiyle gerçekleşmektedir. Gerek saray ve hânedânlarda ve gerekse daha mutedil yerlerde aşçıbaşının niteliksel varlığı oldukça önemlidir. Doğrudan insan sağlığı ve zevkine hitap eden aşçıbaşılar, sunduğu ikramlarla ilgi dairesinden ayrılan her bir ferde kapsamsal yön tayin ederler. Zira sağlıklı ve nezih bir gıda alan bireyin sağlıklı ve nezih düşünceler etrafında olumlu icraatlar yapması beklenir. Güvenilmez bir aşçıbaşı tekelinde yediği yemekten zehirlenen ve mideyi bozan bir insanın düşünce ve icraat dairesi sınırlı bir metrekareyi kapsayacaktır. Ehil olmayıp ölümlere sebebiyet veren aş̧̧başıları anmak bile iç açıcı değildir. Söz konusu hizmet, geçmişten geleceğe her dem vardır. Bakınız; tedip edilmiş hâli, işte kayit altında: 
yanut birdi ögdülmiş aydı ilig

bu işke bütün er kerek ked silig

kişide talusı köni çın kişi

ödürgü angar birgü aş suv işi

bu işke idi çın bütün er tile

bagirsak tapugsak uvutı bile

közi tok kerek ked yime kögli bay

arıglık kerek hem yüzi körki ay

sakınuk kerek din şeri'at bilir

bu mundag kişidin bütünlük kelir

yüzi körki körklüg kerek kılk1 uz

yülüg bolsa bodlug tili köngli tüz

bagırsak kerek ked begini sever

uvutlug kerek ked özini yıgar

ukuşlug kerek hem biliglig kerek

ödi bolsa aşka iriglig kerek

törüçe yorısa tapug kılsa öz

kirürde çıkarda köni tutsa köz

munu aydım emdi ay ilig kişi

bu yanglıg kerek bolsa aşçı başı
Ögdülmis yanıt verdi ve dedi: Ey hükümdar,

bu işe mükemmel ve temiz ruhlu bir insan gerekir.

Insanlar arasında doğru, dürüst ve seçkin olan biri yemek içmek işiyle ilgilenir olmall.

Bu iş için çok dürüst ve doğru bir insan ara; şefkatli, işine gönülden bağlı ve hayâlı oulsun.

Aşçıbaşının gözü tok ve gönlü zengin olmall;

kendi, yüzü ve giysileri ay gibi parlamalı.

Takva sahibi, din ve ilâhî yasaları tanır biri olmalı

böyle kişden doğruluk gelir.

Yüzü ve tavrı güzel, saçı sakalı düzgün ve pir ü pak

bir giysiyle yaklşıklı ve dürüst biri olmalt.

Aşçıbaşı, sadık olmalı ve beyini çok sevmeli;

nefsine hâkim ve hayâ sahibi bulunmalı.

Aşçıbaşı akıllı ve bilgili olmalı;

yemek vakti gelince eli tez olmall.

Usul, erkân çerçevesinde hareket ve hizmet etmeli;

hizmet ederken sürekli önüne bakmall.

Ey hükümdar! İşte söyledim;

aşçıbaşı dediğin böyle olur.

$(2828,2829,2830,2843,2844,2854,2867,2868,2869,2877)$

\section{h) Kendisinden Emin Olunan Bir İçkicibaşı Nasıl Olmalıdır?}

Kuranıkerim, bu hususta; içecek tabirini kullanır ve bununla alkollü içecekleri kasteder. Aynı zamanda Allah'tan geldiği hâliyle içkiyi yasak eder. Yani; ilâhî buyruğa göre içki içmek haramdır. Bu konuda Şeyhî Yûsuf Sinân Germiyânî, Dîvân'ında "şi'r-i acîbe" adını verdiği bir şiirde lafzen ve manen şu kaydı düşer:

Pîş-i to-be nûş-1 şîîn-lebet

Lâ-yehillu'ş-şurbu an hamrin-harâm

Mülemma olduğu gözlemlenen söz konusu ikilik, "senin huzurunda tatlı dudaklarından içince; haram olan başka bir içkiyi içmek helal sayılamaz" anlamını vermektedir. Burada; bezm-i eleste bir gönderim söz konusudur. Söz konusu akdin bozulmaması gerektiği telkin edilmektedir.

Düşülen kayıtlardan ayrık olarak Kutadgubilig, içki tabiriyle alkollü ve alkolsüz her nevi içeceği kasteder. Madde kullanmak, yasalarca yasak kılınmış olduğu gibi sıhhat açısından da pek makul addedilemez. İşte; topulmsal bir yaşamsallık ve tercih bürünümünde olan içki ve içkicibaşının tavsifi: 
öz igdiş kerek ked sınamış yılın köngül basmış erse könitmiş yolın bütün çın bagırsak közi kögli tok köni bolsa k1lkı mesel atgu ok

anın ötrü bolsa idiş tutguçı yaragay bu işke yetilgey küçi kamug türlüg otlar idişçi tutar güvariş ya ma'cun ya çurnı katar kurug öl yimiş tut ya içgü süçig anıngdın bolur bu boguzka keçig ukuşlug kerek hem bilig ked bilir ukuşlug kişidin kişilik kelir idişçi başı ked kuyug er kerek köni tutsa ötrü köngül ög yürek könilik öze işlese iş bütün yakurmasa özke yaragsız otun bu yanglıg bulunsa idişçi baş1 angar birse bolgay idişçi işi
$\ddot{O} z$ kardeşlerinden veya uzun yıllar iyice sınamış, nefsine hâkim ve doğru yolda yürüyen biri olmall. Güvenilir, doğru, sadık, gözü ve gönlü tok; doğası da atılan ok gibi doğru olmalı.

Bu işe içkiyi iyi koruyan ve onu hazırlamaya muktedir bulunan biri uygun olur. İçkicibaşı, her türlü otları hazır bulundurur; hazım, kuvvet veya müshil ilacı yapar. Kuru ve yaş meyve, içecekler ve şarap; boğaza hep onun elinden geçer. $O$ akıllı ve çok bilgin olmall; akıllı insandan insanlık gelir. İçkicibaşıllı için çok titiz insan gerekir; o gö̈l, akıl ve yüreğini doğru tutmal. Bütün işleri doğruluk ile yapmall; uygunsuz ve küstah klişileri yanına koymamall.

Böyle bir içkicibaşı bulunursa; içki işi ona verilebilir.

Bundan başka; içkicibaşı ve içki sunanın biçimsel vasfı da şöyle telkin edilmiş:

yüzi körki körklüg kerek kılkı uz Yüzü gözü güzel, tavır ve hareketi zarif; negü tutsa andın tamar barça tüz sunduğunu zevkle veren olmal ...

(2884, 2885, 2886, 2887, 2889, 2896, 2900, 2901, 2911, 2923)

\section{Nelerdir?}

1) Hükümdara Hizmet Eden Hizmetkârın Vasfı ve Hükümdar Üzerindeki Hakları

Ehl-i hizmet, muhakkak birilerine karşı mesuldür. Yöneticiler de ilâhâ karşı mesuldür. Çok çeşitli meslek erbabının vasıflarını sıralayan Kutadgubilig, hizmetkârların vasıflarını da ayrı ayrı sıralamış ve onların beyleri karşısında ne haklara sahip olduklarını örneklemiştir. Bu örnekleme, hizmetkârların bey karşısındaki haklarını paylaşırken; aynı zamanda Türk töresinde yönetilen konumda bulunan insanlara yapılan muameleyi de izah etmiştir. Bakınız; söz konusu durumun ezgisel yansimasi:

eng aşnu yigü içgü birgü kerek tapıngu itiglerin itgü kerek bu tabgı üçün beg ötegü hakın an1 edgü tutgu bagirsaklıkın $(2958,2965)$
Ona ilk önce yiyecek ve içecek vermek, onun hizmet araçlarını hazırlamak gerek. Hizmetleri için bey, ehl-i hizmetin hakkını ödemeli; onlara şefkatle muamele etmeli. 
Beyin hizmetkâra karşı tavrı ve ondan yararlanma ölçütü, bakınız nası1 örneklenmiş:

boguz todnur aşnu kişi yılkınıng Insan önce hayvanın karnını doyurur;

basa asgı kötrür bu yalnguk anıng sonra da ondan yararlanır.

tapugka körü birgü edgü açıg

Hizmetine göre ona bol ihsanda bulunmall;

yalıngnı bütürgü todurgu açıg

çıplaksa giydirmeli, açsa doyurmalı.

ispat1:

Hükümdar ve hizmetkâr arasındaki ilişki, alıcı ve satıcı arasındaki ilişkiye teşbih olunmuş. İşte

satıgçı birür neng angar mün sanı

Satıcı mâl verir ve bu ona sermaye olur;

alılı alır ilde evrer anı

alan onu ilden ile dolaşttrır.

(2995)

İşte; bu biçimde hizmetkârını gözeten beyin mâlı da ilden ile diyardan diyara nâm salar, kâm alır. Beyin sermâyesi de yanına kâr kalır. Hizmetkârını iyi seçip gözeten bey ve erdemli çalışan her bir erbab-1 meslek, âbâd u şâd olur...

\section{Sosyo-Algısal ve Düşünsel Açıdan Kutadgubilig'in Ashâb-ı Ahlâk Madde Başını Beyan ve Tahlil Eder}

Etik olarak adlandırılabilecek ahlâk; dinî, ilmî, içtimaî, askerî, mâlî ve harsî birçok hususun göz bebeğini oluşturur. Hz. Peygamber'in ahlâkının Kuranıkerim olduğu ve O'nun ahlâkıyla yani dolaylı olarak Kuran ahlâkıyla ahlâklanmanın yaraşır olduğu çok defalar yazılıp, dillendirilmiştir. Algı bakımından Kuranıkerim'den mülhem olduğu varsayılabilecek Kutadgubilig deinsan ilişkileri ve iletişiminde tavrın ne olması gerektiğini ahlâkî boyutuyla ele almıştır. Esere göre; vezir mahdumu Ögdülmiş ve amcası Odgurmuş arasında geçen ikili görüşmeler, on sekiz ayrı başlık altında yaşamsal ahlâkın çerçevesini tayin ediyor. Bu doğrultuda; bir sosyo-kültürel yaşam formeli çizen madde başı, örnekleyici bir istikamette dikkatlere sunuluyor.

\section{a) Kapı Hizmetkârları ile İliş̧ ki Nasıl Olmalıdır?}

yakınlık tilese özüng beg bile

kapugdaki birle yakınlık tile

ulugluk tapayın tise sen özün

er at birle yakş1 yorı ay tüzün
Sen beye yakın olmak istersen;

kapıdakilerle yakınlık kurmaya çalış.

Sen büyüklük bulmak istersen;

ey halim insan! Hizmetkârlara iyi davran.

(4171-4172)

Esere göre; ileri seviyeli insanlara ulaşmanın ve onlardan fayda görmenin ön koşulu, hizmetkârlar ve kapıcılardan geçer. Onlarla iyi geçinen beye de emeline de erişir.

\section{b) Avam ile İlişsi Nasıl Olmalıdır?}

Kutadgubilig, önce avamı tarif eder. Ardından avam ile kurulacak ilişkinin ne biçimde olması gerektiğini telkin eder. İnsanlar ya statü sahibidir, ya siradan. Siradan insanların birbirleriyle münasebetleri de sıradan olur. Statü sahibi insanların kendi çevrelerinde olan münasebetleri ise; daha çok seçkindir. İşte; statü sahibi bir insanın avama yaklaşımı ve avamla olacak münasebetinin sırları: 

k1lısız bolurlar kara 'am budun
Avam halk, görgüsüz olur; ilişkilerinde de
törü yok toku yok katılmış ödün
ne yol ne de yordam vardir.
olarka yine ök katıl ay kadaş
Onlarla her demde ilişki kur;
birü tur olarka yigü içkü aş
Onlarla otur kalk; ye iç.
tilin sözle yumşak negü kolsa bir
Yumuşak dille konuş, istediklerini ver;
birigli alır kör anıng asg1 yir
veren muhakkak alır ve kârını görür.
öküş sözleme söz serin til küdez
Çok söz söyleme; kendini koru ve hâkim davran;
öküş sözlemiş söz suvı kaldı az
onlarla çok konuşursan; değerin kalmaz.

(4321, 4330, 4331, 4332)

\section{c) Nesl-i Peygamber ile İlişki Nasıl Olmalıdır?}

Beye yakın bir kimsenin hizmetkârlar ve bey yakınları dışında; ilişki içinde bulunacağı en önemli güruh, nesl-i peygamberdir. Kitaba göre; nesl-i peygamberle iyi geçinmek, kişinin bey yanındaki itibarını arttıracağı gibi; ona dünya ve ahiret saadeti de sunacaktır. İşte; manzum terkimi:

Olarda biri savçı urgı turur

bularnı agir tutsa kut kıv bulur

için irtemegil ya kılkın tözin

meger tilde tengsiz yoritsa sözin
Nesl-i peygamberle ilişkide bulunursan;

onlara hürmet ve hizmet et; sevinen sen olursun.

A ğızlarından yakışıksız bir söz çıkmadıkça;

onların içini dışını aslını esasını araştırma. $(4337,4340)$

\section{ç) Bilge Âlimler ile İlişki Nasıı Olmalıdır?}

Âlimler, kategorisinin vasıflarını taşıdığı müddetçe; toplumsal yaşantının her ayğı için kaydadeğer ve takdire şayandır. Bilge bir kişilik tarafından kaleme alnımış Kutadgubilig, bakınız, ilm ve âlim hususunda neler paylaşmış:

olarnı katıg sev agırla sözin

biliglerin ögren öküş ya azın

nengingde ülüg k1l süçig söz bile

aş içgü yitürgil tapug kıl küle

katılgıl bularnıng bile edgüleş

kutadgay sanga iki ajun ulaş
Onlart pek çok sev, onlardan hürmetle bahset;

onların bilgilerinden az ya da çok ögren.

Onlara mâlından hisse ayır, onlarl yedir içir;

güler yüz ve tatlı sözle hizmetlerinde bulun.

Bunlarla iyi ilişkiler kur, böylece mutlu olursun;

iki cihan saadetin kaçınılmaz olur.

$(4342,4348,4354)$

\section{d) Hekimler ile İlişki Nasıl Olmalıdır?}

Hekim, hikmet sahibi demektir. Hekimin hikmeti, tıbbidir. Tıp, insanlık için; sağlıklı yaşam tesis eder. Bakınız; hekimlerle kurulacak münasebet, nasıl olmalı:

olarda birisi otace durur

kamug ig togaka bu emçi erür

bularnı yime edgü tutg1l yakın

kereklig kişi bu küdezgil hakın
Bunlardan birisi hekimlerdir;

bütün hastalık ve ağrllarl, bunlar tedavi eder.

Bunlara karşı iyi davran, onları kendine yakın tut;

bunlar gerekli kişilerdir; haklarını gözet. 
$(4356,4360)$

\section{e) Efsuncular ile İlişki Nasıl Olmalıdır?}

Eski devirlerde; metafiziksel sıkıntıları giderenler, bu adla anılırdı. Bir önceki madde başı, hastalıklara karşı daha çok tıbbi çözümler sunarken; ilgili madde başı, hastalıklara, dinî-mitik çzö̈̈mler arar. Eser, hekimler ve efsuncuların sağlık konusunda bir türlü uzlaşamadıklarını kaydeder. Esere göre; biri ilacı, diğeri muskayı tasviye eder. Eser, efsuncularla kurulacak ilişkiyi şu biçimde tasvir etmiştir:

bularka yime ök katılgu kerek

bu yıl yeklig igke okıgu kerek (4362)

\section{f) Rüya Tabircileri ile İlișki Nasıl Olmalıdır?}

Düş, manevî âlemlerin ilhamıdır. Düş yorumu, bir bilene sorulmalıdır. Çünkü düşü, bilip doğru yoran, onu hayra yormuş veya hayra çevirmiş olur. İște; Bilgelik Kitabı'ndaki yansıması:

takı bir bilig kör bu tüş 'ilmi ol

tüşese yoruglı açar edgü yol

udısa bu yalngluk tüşer ök bu tüş

yora bilse terkin kelir agzı tuş

bularıg yime edgü tutgıl kadaş

tilese kadaş tut dilese adaş

(4366, 4367, 4375)
Bunlarla da görüşmek, tanışamak gerekir;

manevi hastalıklar için bunlara okunmak gerekir.

\section{g) Müneccimler ile İlişki Nasıl OImalıdır?}

Müneccim, yıldızbilimci demektir. Bir çeşit anstronom olan müneccimler, gök hesabını tutmaları ve insanın talihine ilişkin bilgi vermeleri dolayısıyla kaydadeğer ve muteberdirler. İyi hesap edilmemiş her iş, bozulur. İşte; dünya ve ahiret hesabı hakkında fikir veren müneccimlere karşı takınılması gereken tavirlar:

kerek dünya işi keek ukbi tut

sakış birle adra tutar bilge büt

ayıt söz olarka yime bütme terk

biligli bayat ol munı tutgu berk

bularıg yime edgü tutgıl yaraş

tilin serme irme köngül kılma baş

$(4383,4390,4391)$

\section{g) Şairler ile İlişki Nasıl Olmalıdır?}

Esere göre; şairler, öven veya yeren söz dizicileridir. Onlarla iyi geçinenin durumu parlaktır. Kötü geçineninse; ancak adı çıkar. İşte ispatı:

\author{
Gerek dünya işi, gerek ahiret işi olsun; \\ bilge kişi, bunları hesap ile zabt eder. \\ Sözü, onlara sor; ama hemen inanma; \\ her şeyi bilen Tanri'dır, O'na kuvvetle bağlan. \\ Bunlara iyi davran, anlaş, zlt gitme; \\ incitecek söz söyleyerek; gönüllerini kırma.
}

\section{Turkish Studies - Language and Literature}

Volume 14 Issue 4, 2019 
olar ögseler ögdi ilke barır

kalı sökseler atı artap kalır (4396)

\section{h) Çiftçiler İle İlişki Nasıl Olmalıdır?}

Çiftçi, ekip biçen, üreten anlamında bir sözdür. Üretici olmazsa; tüketici mağdur ve mahrum kalır. İşte; endişesiz bir yaşam sürmede çiftçilerle münasbetin önemi:

bularnig bile sen kat1l hem karıl

boguzdın sıngar sen sakınçsız tiril

bularnıg bile me katıl ay kadaş

arıg bolga boguzung halal bolga aş
Bunlar överlerse; adın tüm ülkelere yayllır;

ĕger hicvederlerse; adın herp kötü kalır. (4401, 4405)

\section{1) Satıcılar ile İlişki Nasıl Olmalıdır?}

Bir mâlı, tedarik edip satana satıcı denir. Yaşantıda rastlanan insan tiplemelerinden biri de satıcılardır. Satıcılarla kurulacak ilişki nasıl olmalıdır? Kutadgubilig'deki yansıması şöyle:

katıglan olarig idi edgü tut

sening atıng edgün yırak barga büt

bular ol ajunda kör at iltgüçi

isiz edgü erse anı yadguçı

sanga az öküş neng törü kılsalar

yanut kılgu ötrü sevinç bulsalar

asıg yasta yingçe bolur kılkları

katılsa munı ked küdezip yor1

ajunda atıngnı yadayın tise

ümeg edgü tutg1l katılgan usa

(4430, 4431, 4432, 4435)
Sen bunlarla da temas et, ilişki kur;

böylece boğazın konusunda kaygısız yaşa.

Ey kardeş! Bunlarla da ilişki kur, temas et;

Boğazın temiz ve yediğin helal olur.

\section{i) Hayvan Yetiştiricileri ile İliş̧ki Nasıl Olmalıdır?}

Hayvanlar, insan yaşantısına çok çeşitli açıdan yarar sağlar. Değerli bir mâla ulaşmanın en önemli ayağı mâl sahibini aşmaktır. Hayvanın sahibi de yetiştiricisidir. Eserin bu noktaya ilişkin paylaştığı yol yordam şu biçimdedir:

bularka katılsa özüngni tutun

törüsüz tokusuz bolurlar otun

tilin edgü sözle işimsinmegil

basıngan bolurlar biligsiz çigil

$(4447,4448)$
Onlara karşı çok iyi davranmaya gayret et; senin adın da iyilikle çok uzaklara gider, kuşkusuz.

Dünyanın her tarafina adını ulaştıran bunlardır; iyi olsun, kötü olsun adını cihana bunlar yayar.

Sana az veya çok bir şey hediye ederlerse; karşıllı̆ııı vererek; sen de onları sevindirmelisin.

Kâr ve zarar konusunda çok hassas olurlar; onlarla iş görürken bu hususa çok dikkat et.

Dünyada adını yaymak istersen, mümkünse, satıcılara iyi davran.
Bunlar ile ilişkide kendine dikkat et; bunlar; görgüsüz, usulsüz ve kaba olur.

Onlara tatlı söz söyle, fakat arkadaş gibi olma; bunlar, bilgisiz ve haşin olur. 


\section{j) Erbâb-ı Zanaat ile İlişki Nasıl Olmalıdır?}

İnsan yaşamında gerekli olan bir insan taifesi de erbâb-1 zanaattir. Bu kişlere yakın durup, onlarla iyi geçinmek kazanç sağlar. Dünyaya süs veren zanaatkârlar, böylelikle insan yaşamını da süslerler. Bu gibi kimselerle; görüşmek, tanışmak, konuşmak ve ticaret yapmak, insana yarar sağlar. Erbâb-1 zanaatle kurulan ilişsi de en önemli husus, iş bitiminde ustaya, parayı hemen teslim ve takdim etmektir. Aksi hâlde; kişinin adı lekelenir. İşte Nakl-i manzumu:

işing k1lsalar terk terin tegrü bir

yitürgil içürgil aşıng kingrü bir

ayinglamasunlar sini halk ara

atıng artamasun munı ked köre

\begin{abstract}
Ismarladiğı̆ bir işi yaptıklarında;
hizmet haklarını derhal öde, onları, yedir, içir. Çok dikkat et; halk arasında seni kötülemesinler; adına çamur lekesi gelmesin.
\end{abstract}

$(4462,4463)$

\section{k) Yoksullar ile İlişki Nasıl Olmalıdır?}

Herkes, eşit ve üstdüzey olanaklara sahip olamayabiliyor. Yaşamnı sürdürmeye çalışan birçok yoksul var. Bakınız; Kutadgubilig, yoksullara davranmada nelere dikkat edilmesini telkin ediyor:

Yoksullara mâl vermeli, onları yedirip içirmeli; onlardan verilen mâllara karşıllı mâl beklememeli, sadece duaları alınmalı. Böylelikle; insan, cennete erer. Yoksulların işi hâlledilirken; merhametli davranılmalı. Onların yakınlı̆̆ kazanılmalı. Bunları yapan, iyi nam ve şöhret bulur. İki cihanda da aziz olur.

\section{l) Evlilik Nasıl Olmalıdır?}

Allah'ın nebisinin en sevdiği üç şeyden biri evlenmedir. Allah'ın en hoşnut olmadığı helal de boşanmadır. Kutadgubilig, dinibütün bir kadınla evlenmeyi telkin etmektedir. Güzellik ve mâl kaygısı, insanı bitirir diyor. İşte; Allah'ın nebisini mutlu kılacak, Allah'1 küsdürmeyecek bir evliliğin sırları:

kalı evlik almak tilese özüng

talusin tile ked yiti k1l közüng

köki edgü bolsun urug hem tarig

uvutlug sakınuk tilegil arıg

usa ev kızı al elig tegmedük

seningde adın er yüzin görmedük

sini sevge sindin adın bilmegey

yaragsız ya tengsiz kılık kelmegey

özüngde kodı al kisi alsa sen

bedük tüpge yakma bulun bolga sen

yüzi körki kolma kılınç edgü kol

kılınç edgü bolsa yarutgay sini

kisi alma alsa özüngke kurı

sen algıl sakınuk erenler eri
Ĕger, evlenmek istersen;

çok dikkatli ol ve iyi bir kız ara.

Alacağın kişinin soyu sopu ve ailesi iyi olsun;

kendisi de hayâ ve takva sahibi temiz olsun.

El değmemiş, senden başka erkek yüzü görmemiş,

bir aile kızı al.

Böylesi seni sever ve senden başkasını tanımaz;

yaklşıksız, uygunsuz hareketlerde bulunmaz.

Evlenceksen; kendinden alçak biriyle evlen;

kendinden yüksek ailelerle yaklaşma, esir olursun.

Onda yüz güzelliği arama, güzel huy ara;

huyu iyi olursa seni tatmin eder.

Ey takva sahibi kişi! Evlenme;

evlenirsen; kendi dengin ile evlen. 
(4475, 4476, 4477, 4478, 4479, 4482, 4483)

\section{m) Çocuklara Nasıl Terbiye Verilmelidir?}

İşte; Kutadgubilig'den yansımaları:

ogul kız törüse sening ay tengin

evingde igidgil igidme öngin

avurtas1 edgü kişi tut arıg

ogul k1z arıg kopga turgay karıg

ogul kızka ögret bilig hem edeb

angar iki ajun anıng asgı tap

ogulka kisi al kızıg erke bir

sakınçsız tirilgil aya kutlug er

Senin ay gibi bir oğlun veya kızın doğarsa;

onu kendi evinde terbiye et, bu işi başklara verme.

Süt annesi olarak; iyi ve temiz bir hatun tut;

oğlun kizın temiz büyür ve uzun ömürlü olur.

Oğluna kızına bilgi ve edep öğret;

her iki dünyada bu onlar için yararlı olur.

Oğula kız al, kızı ere ver;

ey mutlu insan! Ömrünü dertsiz geçir.

$(4504,4505,4506,4507)$

\section{n) Hizmetçilere Nasıl Davranılmalıdır?}

Eser, hizmetçilere iyi davranılmasını onların maddi ve manevi anlamda gözetilmesini onların çeşitli meslek gruplarında istihdam edilmesini ve içlerinden takva sahibi olanların evlat muamelesine tabi tutulmasinı telkin ve teklif etmektedir.

\section{o) Davete Gitme ve Davet Etme Nasıl Olmalıdır?}

Ahlâkî tutum gösterme konusunda; Ögdülmüş ve Odgurmuş arasındaki son görüşme, davet hususu üzerinedir. Eser, ne tür davet olursa olsun; harama tevessül ve temayül olacaksa reddedilmeli; aksi hâlde nebinin sünneti olmak dolayısıyla kabul edilmelidir, diyor. Birilerini bir yerlere çağırırken de Kuranıkerim' in tekliflerine göre hazırlık yapmanın yaraşır olduğunu, herkese eşit muamele yapacak bir sunumun tercih edfilmesinin ahlâkî durduğunu beyan ediyor.

\section{Sonuç}

Hayli muteber nitelik ve nicelik vasıfların haiz Kutadgubilig, sosyo-kültürel bağlamda algısal ve düşüncesel birçok veri paylaşmaktadır. Bu veridizisi içinde dikkate şayan bir husus da erbâb-1 meslek ve ashâb-1 ahlâktır. Analiz-sentez eksenli hazırlanan söz konusu çalışma; ilk madde başı için 11 ikinci madde başı için 18 ayrı irdeleme sunmaktadır. Her bir madde başı ve madde başlarının bağlamdaşı irdelemeler göstermiştir ki; Kutadgubilig, yaşamın her aşamasını kolaylaştırıcı bir kimlik ve vasıf arz etmektedir. Özgün ve diliçi çevirili metin örnekleri, bazı teville desteklenerek sunumsallığa dönüştürülmüș ve böylelikle Kutadgubilig'in yaşantısal bir boyutu, kolay erișilebilir hâle getirilmiştir. Bu istikamette; söz konusu yazı, insan ilişkileri ve iletişimini daha üstdüzey ve sağlıklı kılmaktadır.

\section{KAYNAKÇA}

Adalığlu, Hasan Hüseyin (2009). "Doğumunun 990. Yılında Yusuf Has Hacib ve Eseri Kutadgu Bilig". İstanbul Üniversitesi Türkiyat Araştırmaları Merkezi ve Türk Dil KurumuSempozyumu, s. 237-253.

Akar, Cüneyt (2016). "Değer Eğitiminde Kutadgu Bilig”. Yûsuf Has Hâcib’in Doğumunun 1000. Yılında Kutadgu Bilig Türk Dünya Görüşünün Şaheseri Uluslararası Sempozyumu, Şen Yıldız Yayıncilik. 
Akgün, Mehmet (1997). “Kutadgu Bilig'de Adil Bir Hükümdar (Devlet Başkanı) Örneği ve Hukukun Üstünlüğü Meselesi”. Yûsuf Has Hâcib ve Ölümsüz Eseri Kutadgu Bilig, Kirgizistan: Manas Ünivsersitesi Yayınları.

Altuntaş, Halil ve Şahin Muzaffer (2011). Kur'an-ı Kerim Meali.Ankara: Diyanet İşleri Başkanlığı Yayınları.

Arat, Reşid Rahmeti (2008). Kutadgu Bilig-Yusuf Has Hacib. II. Basım, İstanbul: Kabalcı Yayınevi.

Aydemir, Özgür Kasım (2013). "Kutadgu Bilig'in Dilinde Bilgi Kavramı ve İşlevi”. Turkish Studies, 8/1, s. 803-810.

Büyükbaş, Hakkı ve Vargün Fahri (2016). "Kutadgu Bilig’de Devlet Yönetimi/Hükümdar-Adalet İlişkisi”. Ardahan Üniversitesi İktisadi ve İdari Bilimler Fakültesi Dergisi, S. 4, s. 27-33.

Debreli, Zekiye Gizem (2016). "Kutadgu Bilig'de Kadın”. Studies of the Ottoman Domain, 6/11, s. 38-60.

Kaya, Umut (2017). "Kutadgu Bilig ve Yusuf Has Hacib’in Eğitimle İlgili Görüşleri”. Düzce Üniversitesi Illahiyat Fakültesi Dergisi, I/I, s. 1-26.

Kesik, Beyhan (2002). ““Muhibbi Divanı’nında Adalet”. Türk Dünyası Araştırmaları, s. 27-240.

Uçar, Erdem (2016). "Kutadgu Bilig'in Kronolojik Kaynakçası (1825-2016) [Tekmilleştirilmiş Versiyon]". Uluslararası Uygur Araştırmaları Dergisi, 6/2015, s. 6-47.

Yıldırım, Ali (2006). “Renk Simgeciliği ve Şeyh Galib'in Üç Rengi”. turkoloji.cu.edu.tr, E.T. 19. 07. 2019, s. 1-13. 